\title{
Suitability of different maize hybrids for development of Plodia interpunctella (Hübner)
}

\author{
Sonja Gvozdenac ${ }^{1}$, Bojan Mitrović ${ }^{1}$, Snežana Tanasković ${ }^{2}$, Jelena \\ Ovuka ${ }^{1}$, Filip Vukajlović ${ }^{3}$, Mladen Tatić ${ }^{1}$, Vojislava Bursić ${ }^{4}$ \\ ${ }^{1}$ Institute of Field and Vegetable Crops, Maksima Gorkog 30, Novi Sad, Serbia \\ ${ }^{2}$ University of Kragujevac, Faculty of Agronomy, Cara Dušana 34, Čačak, \\ Serbia \\ ${ }^{3}$ University of Kragujevac, Faculty of Science, Radoja Domanovića 12, \\ Kragujevac, Serbia \\ ${ }^{4}$ University of Novi Sad, Faculty of Agriculture, Trg Dositeja Obradovića 8, Novi \\ Sad, Serbia \\ Corresponding author: sonja.gvozdenac@ifvens.ns.ac.rs
}

\begin{abstract}
Plodia interpunctella (Hübner), the Indian meal moth (IMM), is a major lepidopteran storage pest worldwide. IMM larvae can be found in high abundance in stored maize and cause huge losses in seed germination and seed viability. This work aimed to assess the susceptibility of six maize hybrids (NS 6140, NS 640, NS 1090, NS 444 - dent type, NS 620k - pop-corn type, Red-aleurone maize - maize with an altered aleuron color) to IMM attack and suitability for pest's development. Standard laboratory diet (SLD) was used as a positive control. Under laboratory conditions, the following IMM life history parameters were monitored: larval mortality, mean developmental duration (egg to adult), adult emergence, adult lifespan and female fecundity. Kernel susceptibility was determined based on the Susceptibility Index (SI). The highest mortality of IMM larvae was on NS 620k (35.25\%) compared to the other maize hybrids (11.2-19.5\%). The highest number of emerged adults was on Red-aleurone maize (17.5), and the lowest on NS 620k (4.0). The longest lifespan was recorded for moths reared on NS 6140 and NS 640 (8.5 and 8.7 days, respectively). The highest female fecundity was on SLD (115.8 eggs), on Red-aleurone maize (44.3 eggs), while females reared on NS
\end{abstract}


$620 \mathrm{k}$ laid the lowest number of eggs (22.8 eggs). Moths reared on NS 620k had the shortest body sizes $(0.9 \mathrm{~cm})$, which indicated reduced moths fitness. SI showed that Redaleurone maize $(\mathrm{SI}=7.79)$ was the most susceptible to IMM attack, while NS $620 \mathrm{k}$ $(\mathrm{SI}=3.08)$ was the least susceptible.

Keywords: Plodia interpunctella, maize hybrids, development, kernel susceptibility.

\section{Introduction}

In Serbia, maize is a predominant crop, cultivated on over $35 \%$ of arable land (Dragović et al., 2003). Also, maize is the most important export crop of Serbia (Anonymous 1, 2016). A crucial factor for successful maize production is the use of seeds of high quality, which can be maintained during long-term storage. To preserve biological and technological seed characteristics and mitigate losses over a long period of time, storages must satisfy a number of requirements (Sečanski et al., 2015). However, a limiting factor for the quality of stored maize seed is the presence of insect pests. During storage, maize seeds are frequently attacked by a number of pests, among which Plodia interpunctella (Hübner, 1813) (Lepidoptera, Pyralidae), the Indian meal moth (IMM), is one of the most important and widespread lepidopteran species (Mohandass et al., 2007) and possibly the most important storage pest worldwide (Han et al., 2016). IMM larvae can be found in high abundance in stored maize (Kaliyan et al., 2005; Arbogast 2007; Throne and Arbogast 2010; Stejskal et al., 2014). The survival of IMM on maize mostly depends on the survival of larvae, since only larvae feed and cause damage (Kaliyan et al. 2005). IMM larvae have a preference for the germinal part of the kernel over the endosperm, and cause losses in seed viability (Abdel-Rahman et al., 1968, Rees, 2004), seed germination (Sallam, 1999) and deterioration of maize quality by contamination with webbing and faeces (Phillips et al., 2000).

Very few maize hybrids and kernel types have been tested for susceptibility to any storage insect pest. However, several studies have been conducted to determine the effect of maize variety on the development and survival of IMM, and to identify different resistant varieties (Abdel-Rahman et al., 1968; Mbata, 1990), but so far the data are scarce. Therefore, the objective of this research was to assess the suitability of different NS maize hybrids for IMM development, and determine their susceptibility to IMM attack.

\section{Materials and methods}

\section{Maize hybrids}

The experiment was carried out using seeds of six maize hybrids: NS 6140, NS 640, NS 1090, NS 444 (dent type), NS 620k (pop-corn type) and Red- 
aleurone maize (maize with an altered aleurone color), obtained from the Institute of Field and Vegetable Crops, Novi Sad, Republic of Serbia. Prior to the beginning of the experiment, kernels were exposed to deep freezing $\left(-80{ }^{\circ} \mathrm{C}\right)$ in order to eliminate the potential presence of other insects and parasites. The kernels were not treated with insecticides after the harvest or before setting up the experiment.

\section{Experimental design}

Parental IMM population was reared on a standard laboratory diet (SLD) for IMM (Silhacek and Miller, 1972) for several years, in transparent plastic containers ( $5 \mathrm{~L}$ ), at $28 \pm 1{ }^{\circ} \mathrm{C}$, R.H. $60 \pm 10 \%$ and $14: 10$ (L:D) photoperiod. Paired moths were transferred from mass rearing containers into glass tubes for oviposition and one-day-old eggs were used for the experiment. The experiment was carried out by placing $100 \mathrm{~g}$ of kernels into $0.25 \mathrm{~L}$ glass jars and adding 50 one-day-old IMM eggs. Jars were sealed with a cotton swab and coated with cotton cloth for proper aeration. The experiment was set up in 4 replicates under the same conditions as in the rearing of parental population.

The following parameters of IMM life history were monitored: larval mortality, mean developmental duration (from egg to adult), adult emergence, adult life span and female fecundity. Readings were repeated every five days, until the last larva pupated. Once the emergence of adults began, assays were checked every $24 \mathrm{~h}$ and the numbers of emerged adults were recorded. Newly emerged unmated adults from the same treatment were immediately paired, and each pair was isolated in a separate test tube to obtain the fecundity data, i.e., the number of laid eggs per female. At the end of the experiment, the mean development duration (MDD) was calculated as the average time (in days) from the start of the experiment until each adult emergence.

The susceptibility of maize hybrids was assessed based on the Susceptibility Index (SI) described by Dobie (1974):

$$
S I=\frac{\left(\ln \left(F_{1}\right)\right)}{D} * 100
$$

ln - the natural logarithm of the mathematical constant $e$

F1 - the average number of emerged moths per treatment

$\mathrm{D}$ - average developmental duration (egg to adult) in days

Seeds were rated as resistant (R), moderately resistant (MR), moderately susceptible (MS) and susceptible (S) according to Mensah (1986) as follows: 


$$
\begin{gathered}
0 \leq S I \geq 2.5(R) \\
2.6 \leq S I \geq 5(M R) \\
5.1 S I \geq 7.5(M S) \\
7.6 \leq S I \geq 10(S)
\end{gathered}
$$

\section{Statistical analysis}

Data were statistically analysed using the IBM SPSS Statistics 21 software package (IBM, 2012). Duncan's multiple range test was performed to analyse differences in life history parameters across maize hybrids. The confidence interval was $95 \%$.

\section{Results and discussion}

\section{Larval mortality and IMM mean developmental duration}

The highest mortality of IMM larvae was recorded on NS 620k, i.e. pop-corn type maize $(35.25 \%)$, and was significantly higher than on the other maize hybrids (11.2-19.5\%). The lowest larval mortality was on SLD $(0.9 \%)$ throughout the experiment (Table 1). The difference among treatments was statistically highly significant $\left(\mathrm{F}=123.3^{* *}, \mathrm{P}<0.01\right)$. Subramanyam (1995) found that IMM larval mortality rate can reach $28 \%$ on yellow maize, as also proven in this experiment.

The results on IMM developmental duration on six maize hybrids are presented in Table 1. The fastest development was on SLD (28 days), while the slowest was on NS 620k (45 days) and NS 1090 (40.1 day). The differences in developmental duration were statistically highly significant $\left(\mathrm{F}=29.8^{* *}, \mathrm{P}<0.01\right)$. As reported by Williams (1964), the duration of IMM development can range from 36 to 327 days. Developmental rate depends on maize variety (AbdelRahman et al. 1968), as well as on kernel damage. Mortality of pre-adult stages appeared to be higher when development was longer (Williams, 1964). Similarly to the present findings, Mbata (1990) reported that the shortest development from egg to adult on whole maize kernels was 31.2 days (tested on 13 varieties), and the slowest 37.0 days.

\section{Adult emergence, lifespan and fecundity}

The highest number of emerged adults was recorded on SLD (30.2) and Redaleurone maize (17.5), with the difference being statistically significant. The lowest number of emerged adults was on NS $620 \mathrm{k}$ (4.0), compared to the other 
hybrids, which were also less suitable for moth development, based on the number of emerged moths (10.5-14.0 moths). There were no statistically significant differences in the number of emerged adults among NS 640, NS 6140 and NS 444, but the overall difference was highly significant $\left(\mathrm{F}=90.0^{* *}\right.$, $\mathrm{P}<0.01)$.

The lifespan of moths differed depending on maize hybrid. The longest lifespan was recorded for moths reared on NS 6140 and NS 640 (8.5 and 8.7 days, respectively), and was significantly higher compared to SLD, NS 620k and Red-aleurone maize seeds $(6.0,6.5$ and 5.5, respectively). The differences were significant $\left(\mathrm{F}=3.29^{*}, \mathrm{P}>0.01\right)$. Subramanyam (1995) reported that the longevity of the adult stage depends primarily on environmental factors (temperature and humidity), the occurrence of mating, oviposition opportunities and the presence or absence of water (or other liquids) for consumption.

Results on total fecundity are also presented in Table 1 . The highest fecundity was recorded for females reared on SLD (115.8 eggs). As for hybrids, significantly higher fecundity was found on Red-aleurone maize (44.3 eggs), compared to the other five hybrids, while females reared on NS 620k laid the lowest number of eggs (22.8 eggs). The difference in fecundity between maize hybrids and SLD was statistically highly significant $\left(\mathrm{F}=754.5^{* *}, \mathrm{P}<0.01\right)$. The values of the mean total fecundity reported in the literature vary widely. Allotey and Goswami (1990) reported 174.2 eggs per female for IMM reared on split maize kernels. Food source is an important factor in determining fecundity, and the fecundity of moths can be influenced by different diets (Mohandass et al., 2007; Fathipour and Naseri, 2011; Madboni and Pour Abad, 2012), with low fecundity indicating a relatively low nutrient medium (Arbogast, 2007). In the research of Mbata (1990), the 13 tested Nigerian maize hybrids were more or less attractive oviposition sites, regardless of the type of maize. This indicated the presence of certain cues, i.e. ovipositional attractants that were not related to the type of maize. Babic et al. (2013) emphasized that the dent type of maize kernels is the softest kernel type since it contains a higher percentage of the floury endosperm. Thus, we can speculate that the easier consumption of dent kernels and the lower energy needed for breaking the kernel pericarp might lead to higher mean fecundity. Opposite results were reported by Predojević et al. (2017), who proved that fecundity is not affected by the maize type (dent, flint, semi-flint). 
Table 1. IMM life parameters on different maize hybrids and SLD

\begin{tabular}{|l|c|c|c|c|c|}
\hline \multicolumn{1}{|c|}{ Hybrid } & $\begin{array}{c}\text { Larval } \\
\text { mortality (\%) }\end{array}$ & MDD (days) & $\begin{array}{c}\text { Number of } \\
\text { moths }\end{array}$ & $\begin{array}{c}\text { Fecundity } \\
\text { (no. of eggs) }\end{array}$ & $\begin{array}{c}\text { Moth lifespan } \\
\text { (days) }\end{array}$ \\
\hline NS 6140 (dent) & $14.4 \pm 1.25 \mathrm{bc}$ & $39.5 \pm 2.08 \mathrm{bc}$ & $14.0 \pm 2.16 \mathrm{bc}$ & $31.9 \pm 4.13 \mathrm{~d}$ & $8.5 \pm 0.56 \mathrm{a}$ \\
\hline NS 640 (dent) & $13.5 \pm 2.08 \mathrm{c}$ & $37.0 \pm 0.81 \mathrm{c}$ & $12.0 \pm 2.38 \mathrm{c}$ & $37.8 \pm 1.28 \mathrm{c}$ & $8.7 \pm 1.70 \mathrm{a}$ \\
\hline NS 1090 (dent) & $16.7 \pm 0.96 \mathrm{~b}$ & $40.1 \pm 0.82 \mathrm{~b}$ & $10.5 \pm 1.29 \mathrm{c}$ & $36.5 \pm 1.29 \mathrm{c}$ & $7.2 \pm 2.21 \mathrm{ab}$ \\
\hline NS 444 (dent) & $11.2 \pm 1.70 \mathrm{c}$ & $38.0 \pm 0.52 \mathrm{c}$ & $12.5 \pm 1.29 \mathrm{c}$ & $36.5 \pm 1.29 \mathrm{c}$ & $7.7 \pm 1.25 \mathrm{ab}$ \\
\hline NS 620k (pop-corn) & $35.2 \pm 2.87 \mathrm{a}$ & $45.0 \pm 0.82 \mathrm{a}$ & $4.0 \pm 1.70 \mathrm{~d}$ & $22.8 \pm 2.08 \mathrm{e}$ & $6.5 \pm 0.58 \mathrm{~b}$ \\
\hline Red-aleurone maize & $19.5 \pm 2.50 \mathrm{~b}$ & $36.7 \pm 1.71 \mathrm{c}$ & $17.5 \pm 1.29 \mathrm{~b}$ & $44.3 \pm 2.65 \mathrm{~b}$ & $5.5 \pm 1.29 \mathrm{~b}$ \\
\hline SLD & $0.9 \pm 0.25 \mathrm{~d}$ & $28.0 \pm 0.81 \mathrm{~d}$ & $30.2 \pm 1.26 \mathrm{a}$ & $115.8 \pm 1.71 \mathrm{a}$ & $6.0 \pm 0.00 \mathrm{~b}$ \\
\hline F value & $\mathbf{1 2 3 . 3 * *}$ & $\mathbf{2 9 . 8 * *}$ & $\mathbf{9 0 . 9}^{* *}$ & $\mathbf{7 5 4 . 5 * *}$ & $\mathbf{3 . 2 9}^{* *}$ \\
\hline
\end{tabular}

Mean values $\pm \mathrm{SD}$, Values in the same column followed by the same letter are at the same level of significance, ** - $\mathrm{P}<0.01,{ }^{*}$ - $\mathrm{P}<0.05$, ns - $\mathrm{P}>0.05$,

\section{Moth body size}

Moths reared on SLD had the largest body sizes (on average $1.85 \mathrm{~cm}$ ). The smallest average body sizes were measured for moths reared on NS 620k i.e. pop-corn type $(0.9 \mathrm{~cm})$, while the body sizes of moths on the other five maize hybrids did not differ significantly $(1.10-1.50 \mathrm{~cm})$. Differences in the body size of moths between maize hybrids were statistically highly significant $\left(\mathrm{F}=19.57^{* *}\right.$, $\mathrm{P}<0.01)$. Results are presented in Graph 1.

Graphic 1. Body lengths of moths developed on different maize hybrids

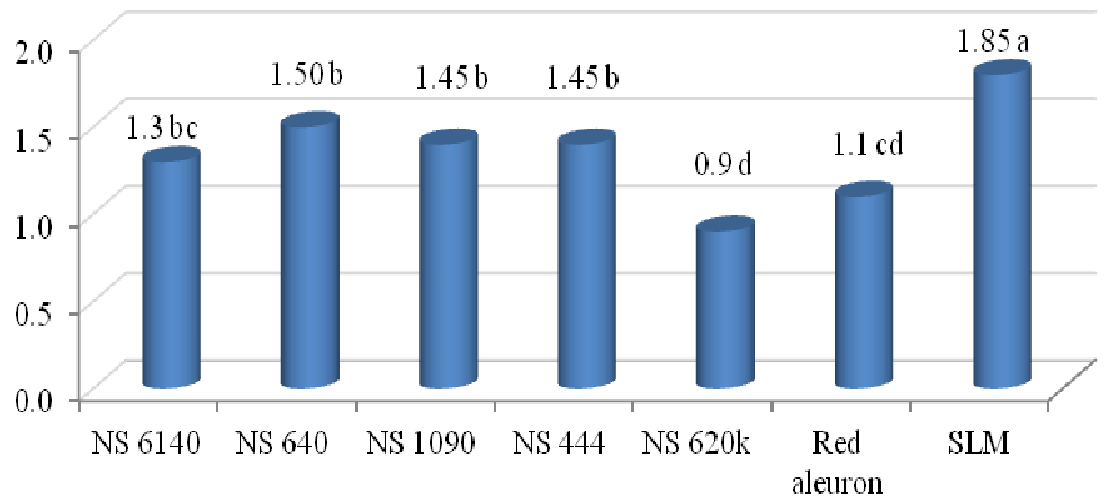

Values followed by the same letter in the graph are at the same level of significance 


\section{Maize hybrid susceptibility to IMM}

The calculated susceptibility indices (Table 2) indicate that Red-aleurone maize was the most susceptible to IMM attack $(\mathrm{SI}=7.79)$, while the pop-corn type, NS 620k, was less suitable (SI = 3.08). However, SLD was expectedly the most suitable medium for IMM development, with the highest value of SI (SI = 12.17).

Table 2. Susceptibility of different maize hybrids and SLD to IMM attack

\begin{tabular}{|l|r|}
\hline \multicolumn{1}{|c|}{ Hybrid } & $\begin{array}{c}\text { Susceptibility } \\
\text { Index }\end{array}$ \\
\hline NS 6140 (dent) & 6.68 \\
\hline NS 640 (dent) & 6.71 \\
\hline NS 1090 (dent) & 5.86 \\
\hline NS 444 (dent) & 6.64 \\
\hline NS 620k (pop-corn) & $\mathbf{3 . 0 8}$ \\
\hline Red-aleurone maize & 7.79 \\
\hline SLD & $\mathbf{1 2 . 1 7}$ \\
\hline
\end{tabular}

Due to the soft endosperm, dent type maize is more susceptible to insect pests, both in the field and in storage (Paliwal et al., 2000), while popcorn maize is a popular type of maize, characterised by a very hard outer layer, a corneous endosperm, and a small portion of soft starch. These characteristics make it more resilient to insect attack, as also proven in this study. Also, as found by Babic et al. (2013), dent type is the softest type of kernel since it contains a higher percentage of the floury endosperm, which makes the kernel easy to break and be attacked by insects.

Limonta et al. (2013) tested the susceptibility of different maize hybrids to IMM and showed that larval penetration into the kernel was influenced by maize embryo properties. Seeds lacking embryos were less damaged, and therefore showed the lowest mean number of adult insects.

Since the type and proportion of the endosperm in maize are directly associated with kernel hardness (Vieira Filho et al., 2015), it was expected that kernel hardness would significantly affect the life history of IMM, namely hybrids with harder kernels would be less vulnerable to damage caused by this pest. This is why kernel hardness should be an important parameter when choosing maize hybrid for growing and storage. Also, kernel hardness testing and continuous improvement of kernel resistance to attacks by storage insect pests can reduce future losses in the quality and quantity of stored grains (Gvozdenac et al., 2017). 


\section{Conclusion}

The obtained results showed that:

- the highest mortality of IMM larvae (35.25\%) and the slowest development (45 days) were on pop-corn maize (NS 620k),

- the highest number of emerged adults (17.2 specimens) and the highest female fecundity (44.3 eggs) were on Red-aleurone maize, while the lowest values for the number of emerged adults (4 specimens) and female fecundity (22.8 eggs) were on pop-corn maize.

Susceptibility index values revealed different degrees of suitability of the tested maize hybrids as nutritional media for IMM. The highest suitability was exhibited by Red-aleurone maize ( $\mathrm{SI}=7.79$ ), while pop-corn maize (NS 620k) was an inappropriate medium $(\mathrm{SI}=3.08)$ for IMM development.

\section{Acknowledgement}

This work is part of Projects TR 31073 funded by the Ministry of Education, Science and Technological Development.

\section{References}

Abdel-Rahman H.A., Hodson A.C., Christensen C.M. (1968): Development of Plodia interpunctella ( $\mathrm{Hb}$.) (Lepidoptera: Phycitidae) on different varieties of corn at two levels of moisture. Journal of Stored Product Research, 4: 127-133.

Allotey J., Goswami L. (1990): Comparative biology of two phyctid moths, Plodia interpunctella (Hübn.) and Ephestia cautella (Wlk.) on some selected food media. Insect Science and its Application, 11: 209-215.

Anonymous 1 (2016): Corn Production, Processing and Market. Current Report September 2015. Ministry of Agriculture and Environmental Protection of the Republic of Serbia. http://www.mpzzs.gov.rs/dokumenti/.

Arbogast R.T. (2007): A wild strain of Plodia interpunctella (Hübner) from farm-stored maize in South Carolina. Effect of temperature on mating, survival, and fecundity. Journal of Stored Product Research, 43: 503-507.

Babić LJ., Radojčin M., Pavkov I., Babić M., Turan J., Zoranović M., Stanišić S. (2013): Physical properties and compression loading behavior of corn seed. International Agrophysics, 27: 19-126.

Dobie P. (1974): The laboratory assessment of the inherent susceptibility of maize varieties to post-harvest infestation by Sitophilus zeamais. Journal of Stored Product Research, 10:183-197.

Dragović S., Maksimović L., Jocković Đ. (2003): Značaj navodnjavanja u unapređenju proizvodnje kukuruza u Srbiji. Vodoprivreda, 35: 111-120.

Fathipour Y., Naseri B. (2011): Soybean cultivars affecting performance of Helicoverpa armigera (Lepidoptera: Noctuidae), In: Ng T. B. (Ed.), Soybean - Biochemistry, Chemistry and physiology, 642, InTech, Rijeka, Croatia. 
Gvozdenac S., Tansković S., Milošević B., Dolapčev A., Ovuka J., Tatić M., Prvulović D., Vukajlović F. (2017): Razvoj Plodia intepunctella (Hübner) na zrnima gajenih biljaka iz porodice Poaceae. Zbornik rezimea radova. XIV Savetovanje o zaštiti bilja, 27. Novembar-01. Decembar 2017., Zlatibor, Srbija, 60.

Han G.D., Kwon H., Na J., Kim Y.H., Kim W. (2016): Sensitivity of different life stages of Indian meal moth Plodia interpunctella to gaseous chlorine dioxide. Journal of Stored Products Research, 69: 217-220.

Kaliyan N., Carrillo M.A., Morey V., Wilcke W.F., Cannon C.A. (2005): Indian meal moth survivability in stored corn with different levels of broken kernels. The Great Lakes Entomologist., 38 (3/4): 177-185.

Limonta L., Locatelli D.P., Sangiorgio S., Consonni G. (2013): Susceptibility of maize variants to Plodia interpunctella. Italian Journal of Food Science, 25 (3): 283-288.

Madboni M. A. Z., Pour Abad R.F. (2012): Effect of different wheat varieties on some of developmental parameters of Anagasta kuehniella (Lepidoptera: Pyralidae). Munis Entomology and Zoology, 7 (2): 1017-1022.

Mbata G.N. (1990): Suitability of maize varieties for the oviposition and development of Plodia interpunctella (Hübner) (Lepidoptera: Pyralidae). Tropical Pest Managment, 36 (2): 122-127.

Mensah G.W.K. (1986): Infestation potential of Callosobruchus maculatus (F) (Coleoptera: Bruchidae) on cowpea stored under subtropical conditions. Insect Science and its Application, 7 (6): 718-784.

Mohandass S., Arthur F.H., Zhu K.Y., Throne J.E. (2007): Biology and management of Plodia interpunctella (Lepidoptera: Pyralidae) in stored products. Journal of Stored Product Research, 43: 302-311.

Paliwal R.L., Granados G., Lafitte H.R., Violic A.D., Marathée J.P. (2000): Tropical maize: improvement and production. FAO Plant Production and Protection Series. 28. FAO, Rome, Italy

Phillips T.W., Berbert R.C., Cuperus G.W. (2000): Post-harvest integrated pest management. In: Francis F.J. (Ed.) Encyclopedia of Food Science and Technology, $2^{\text {nd }}$ ed. Wiley Inc., New York, 2690-2701.

Predojević D., Vukajlović F., Tanasković S., Gvozdenac S., Pešić S. (2017): Influence of maize kernel state and type on life history of Plodia interpunctella (Lepidoptera: Pyralidae). Journal of Stored Product Research, 72: 121-127.

Rees D. (2004): Insects of stored products. CSIRO Publishing, Collingwood, Australia, p. 181.

Sallam N.M. (1999): Danilo Mejia. In: ISIPE, F.A.O. (Ed.), Insect Damage: Damage on Post-harvest, p. 18.

Sečanski M., Mirić M., Radenović Č., Marković K., Jovanović Ž., Popović A. (2015): Značaj kontinuiranog unapredjenja proizvodnje i kontrole osnovnog semena zp hibrida kukuruza. Selekcija i semenarstvo, 21 (2): 103-114.

Silhacek D.L., Miller G.L. (1972): Growth and development of the Indian meal moth Plodia interpunctella (Lepidoptera: Phycitidae) under laboratory mass-rearing conditions.Annals of the Entomological Society of America, 65: 1084-1087.

Stejskal V., Aulický R., Kucerova Z. (2014): Pest control strategies and damage potential of seed-infesting pests in the Czech stores - a review. Plant Protection Science, 50: 165-173.

Subramanyam B., Hangstrum D. (1995): Integrated Management of Insects in Stored 
Products. Marcel Dekker Inc., p 419.

Throne J.E., Arbogast R.T. (2010): A computer model for simulating population development of the Indian meal moth (Lepidoptera: Pyralidae) in stored corn. Journal of Economic Entomology, 103(4): 1503-1507.

Vieira Filho J.A., Garcia E.A., Seraphim O.J., Floriano Murakami E.S., de Britto Molino A., Conceiçao dos Santos G. (2015): Maize kernel size and texture: production parameters, quality of eggs of the laying hens and electricity intake. Acta Sci., 37 (3): 301-306.

Williams G.C. (1964):. The life history of the Indian meal-moth Plodia interpunctella (Hübner) (Lep. Phycitidae) in a warehouse in Britain and on different foods. Annals of Applied Biology, 53: 459-475. 


\title{
POGODNOST RAZLIČITIH HIBRIDA KUKURUZA ZA RAZVIĆE PLODIA INTERPUNCTELLA (HÜBNER)
}

\author{
Sonja Gvozdenac ${ }^{1}$, Bojan Mitrović ${ }^{1}$, Snežana Tanasković ${ }^{2}$, Filip Vukajlović ${ }^{3}$, \\ Jelena Ovuka ${ }^{1}$, Mladen Tatić ${ }^{1}$, Vojislava Bursićc ${ }^{4}$ \\ ${ }^{1}$ Institut za ratarstvo i povrtarstvo, Novi Sad, Srbija \\ ${ }^{2}$ Univerzitet u Kragujevcu, Agronomski fakultet, Čačak, Srbija \\ ${ }^{3}$ Univerzitet u Kragujevcu, Prirodno-matematički fakultet, Kragujevac, Srbija \\ ${ }^{4}$ Univerzitet u Novom Sadu, Poljoprivredni fakultet, Novi Sad, Srbija
}

\begin{abstract}
Rezime
Plodia interpunctella (Hübner), bakrenasti moljac (BM), jedna je od značajnijih štetočina u skladištima širom sveta. BM larve se mogu naći u velikom broju u skladištenom kukuruzu, što uzrokuje ogromne gubitke $u$ vidu smanjenja klijavosti i vitalnosti semena. Cilj rada je da se proceni pogodnost (podložnost) šest hibrida kukuruza (NS 6140, NS 640, NS 1090, NS 444 - tip zubana, NS 620k - tip kokičara, Crveni kukuruz - tip kukuruza sa izmenjenom, crvenom bojom aleurona) za razvoj BM. Standardna laboratorijska podloga (SLP) korišćena je kao kontrola. U laboratorijskim uslovima praćeni su sledeći parametri: smrtnost larvi, srednje vreme razvića (od jaja do leptira), eklozija leptira, dužina života leptira i fekunditet ženki. Osetljivost/podložnost zrna određena je na osnovu indeksa osetljivosti (SI). Najveća smrtnost BM larvi zabeležna je na NS $620 \mathrm{k}(35,25 \%)$, u poređenju sa drugim hibridima kukuruza (11,2-19,5\%). Najveći broj eklodiranih leptira bio je na Crvenom kukuruzu $(17,5)$, a najniži na NS 620k $(4,0)$. Najduži životni vek zabeležen je kod leptira odgajanih na NS 6140 i NS 640 (8,5 dana, odnosno 8,7 dana). Najveći fekunditet su imale ženke odgajane na SLP (115,8 jaja), dok je među hibridima kukuruza najviši bio na Crvenom kukuruzu (44,3 jaja), a najmanji broj jaja položile su ženke sa NS 620k (22,8 jaja). Leptiri odgajani na NS 620k imali su u proseku najkraće dužine tela $(0,9 \mathrm{~cm})$, što ukazuje na smanjene telesne sposobnosti. Prema indeksu osetljivosti (SI), Crveni kukuruz (SI $=7.79)$ bio je najosetljiviji, odnosno najpogodniji za razvoj BM, dok je NS 620k (SI = 3.08) bio manje pogodan.
\end{abstract}

Ključne reči: Plodia interpunctella, hibridi kukuruza, razvoj, podložnost zrna. 